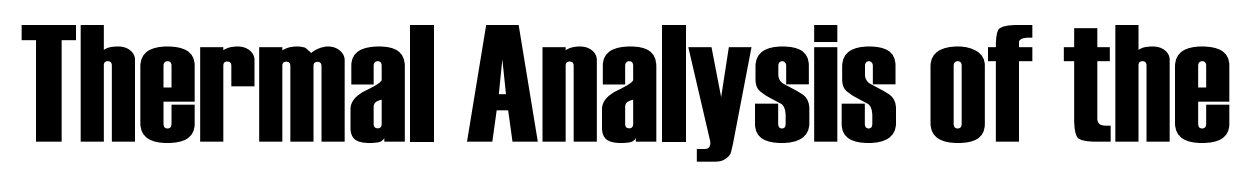
Divertor Primary Heat Iransfer System Piping During the Gas Baking Progess 
This report was prepared as an account of work sponsored by an agency of the United States Government. Neither the United States Government nor any agency thereof, nor any of their employees, makes any warranty, express or implied, or assumes any legal liability or responsibility for the accuracy, completeness, or usefulness of any information, apparatus, product, or process disclosed, or represents that its use would not infringe privately owned rights. Reference herein to any specific commercial product, process, or service by trade name, trademark, manufacturer, or otherwise, does not necessarily constitute or imply its endorsement, recommendation, or favoring by the United States Government or any agency thereof. The views and opinions of authors expressed herein do not necessarily state or reflect those of the United States Government or any agency thereof. 


\title{
THERMAL ANALYSIS OF THE DIVERTOR PRIMARY HEAT TRANSFER SYSTEM PIPING DURING THE GAS BAKING PROCESS
}

\author{
Graydon L. Yoder \\ Karen Harvey \\ Juan Ferrada
}

Date Published: December 2010

\author{
Prepared by \\ OAK RIDGE NATIONAL LABORATORY \\ Oak Ridge, Tennessee 37831-6283 \\ managed by \\ UT-BATTELLE, LLC \\ for the \\ U.S. DEPARTMENT OF ENERGY \\ under contract DE-AC05-00OR22725
}





\section{THERMAL ANALYSIS OF THE DIVERTOR PRIMARY HEAT TRANSFER SYSTEM PIPING DURING THE GAS BAKING PROCESS}

December 2010

Grady Yoder

Juan Ferrada

Jan Berry

TCWS WBS Team Leader

Brad Nelson

U.S. ITER Chief Engineer
Date

Date

Date

Date 



\section{CONTENTS}

\section{Page}

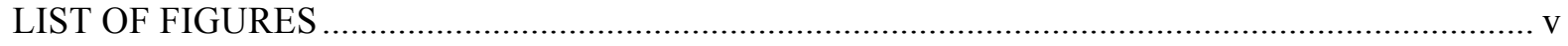

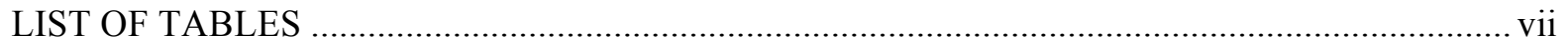

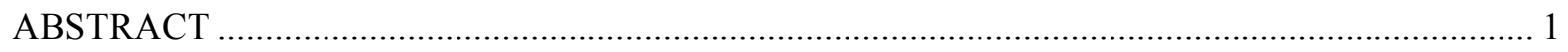

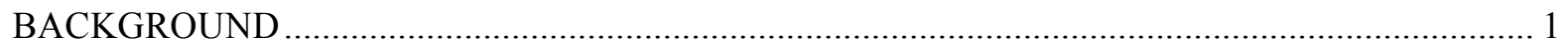

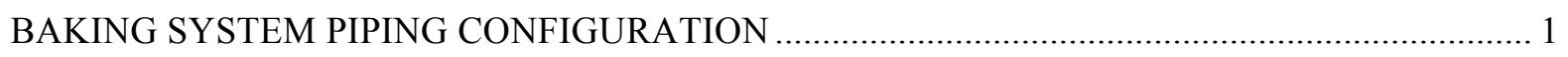

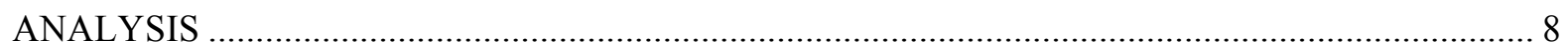

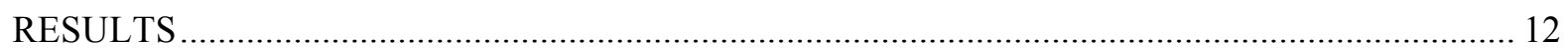

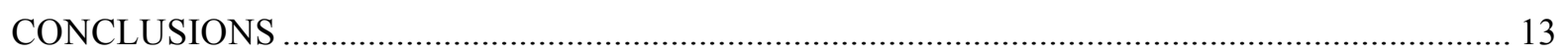

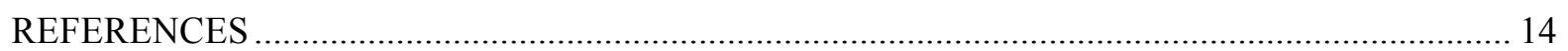





\section{LIST OF FIGURES}

Figure

Page

1. Baking Gas Supply System — Heat Exchanger and Initial Piping................................... 2

2. Layout of Baking System Piping........................................................................... 2

3. Baking System Piping Connections to Divertor Distribution Header............................... 3

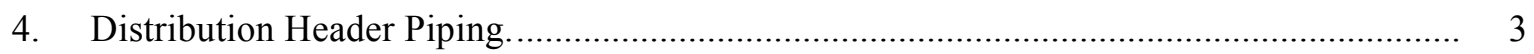

5. Connection of Most Distant Branch Piping to Distribution Header................................... 4

6. Remainder to Divertor Branch Piping .................................................................... 4

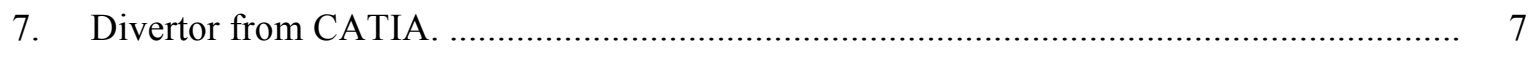

8. Cross Section of a Divertor Cassette. ...........................................................................

9. Representation of a Generic Pipe Support................................................................. 10

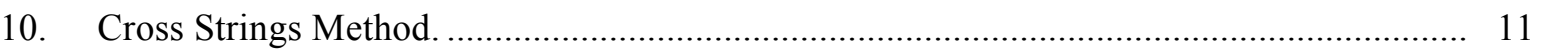





\section{LIST OF TABLES}

Table

Page

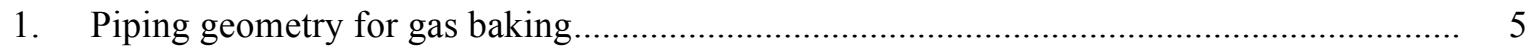

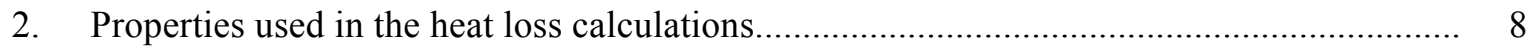

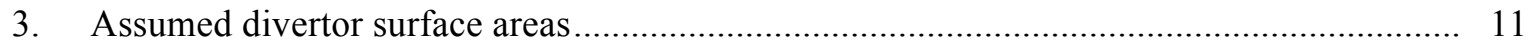

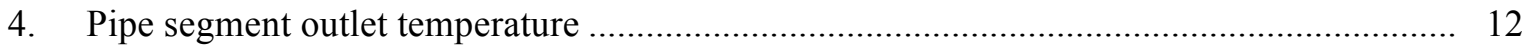





\begin{abstract}
A preliminary analysis has been performed examining the temperature distribution in the Divertor Primary Heat Transfer System (PHTS) piping and the divertor itself during the gas baking process. During gas baking, it is required that the divertor reach a temperature of $350^{\circ} \mathrm{C}$. Thermal losses in the piping and from the divertor itself require that the gas supply temperature be maintained above that temperature in order to ensure that all of the divertor components reach the required temperature. The analysis described in this report was conducted in order to estimate the required supply temperature from the gas heater.
\end{abstract}

\title{
BACKGROUND
}

Baking of vacuum-exposed components in ITER is required to prevent contamination of the plasma after surfaces have been exposed to air, steam, etc. Water baking is performed at elevated temperatures $\left(\sim 240^{\circ} \mathrm{C}\right)$ in order to drive these contaminants from the surfaces exposed to vacuum in preparation for renewed plasma operation. The baking technique is required because many exposed surfaces are hidden, and it is not possible to perform mechanical cleaning. In addition, during deuterium-tritium (D-T) operation, the divertor will trap tritium because beryllium eroded from the first wall will be carried to the divertor and co-deposited with incoming tritium. The ITER tritium operating limit is presently $700 \mathrm{~g}$, and it has been estimated that only $1500-5000$ pulses will be required to reach that limit. This means that the tritium inventory limit will be reached in only $\sim 0.4-1.2$ divertor lifetimes. ${ }^{1}$ It is therefore very desirable to develop methods to remove the tritium before this limit is reached. Because many of the divertor surfaces are hidden, and will not allow mechanical cleaning, divertor baking is required to effect tritium removal. A baking temperature of $350^{\circ} \mathrm{C}$ is necessary to effectively "bake off" the tritium. ${ }^{1}$ This temperature is high enough that it precludes the use of high-temperature water as the baking fluid since required operating pressures would be extremely high (saturation pressure at $350^{\circ} \mathrm{C}$ is over $16.5 \mathrm{MPa}$ ). Gas baking has therefore been selected as the preferred method of increasing divertor temperatures to the required $350^{\circ} \mathrm{C}$ (steam is not practical at this temperature because saturation pressure is over $16 \mathrm{MPa}$ ).

Compared to liquids, gases have a very low density, and a low capacity for transporting heat on a volumetric basis. The piping length between where the baking gas is introduced and the divertor is over $200 \mathrm{~m}$ in length. Since there are thermal losses from this piping as well as the divertor itself, a significant gas temperature decrease could occur just getting the gas to the divertor. It is therefore necessary to determine what the inlet gas temperature must be in order to ensure that the divertor achieves a $350^{\circ} \mathrm{C}$ temperature during the baking process.

\section{BAKING SYSTEM PIPING CONFIGURATION}

The baking gas supply piping assumed in this report starts at the gas heater system located on level 4 of the ITER Tritium building. The heater (shown in pink in Fig. 1) is assumed to be the hot gas supply point. Piping segments are numbered from this point. This numbering scheme is used in the remainder of this report to identify piping location within the gas baking pipe system. Piping dimensions were collected from CATIA drawings and used to estimate thermal losses.

Figure 2 shows the second group of piping as well as the overall gas baking piping layout in relation to the distribution system. 


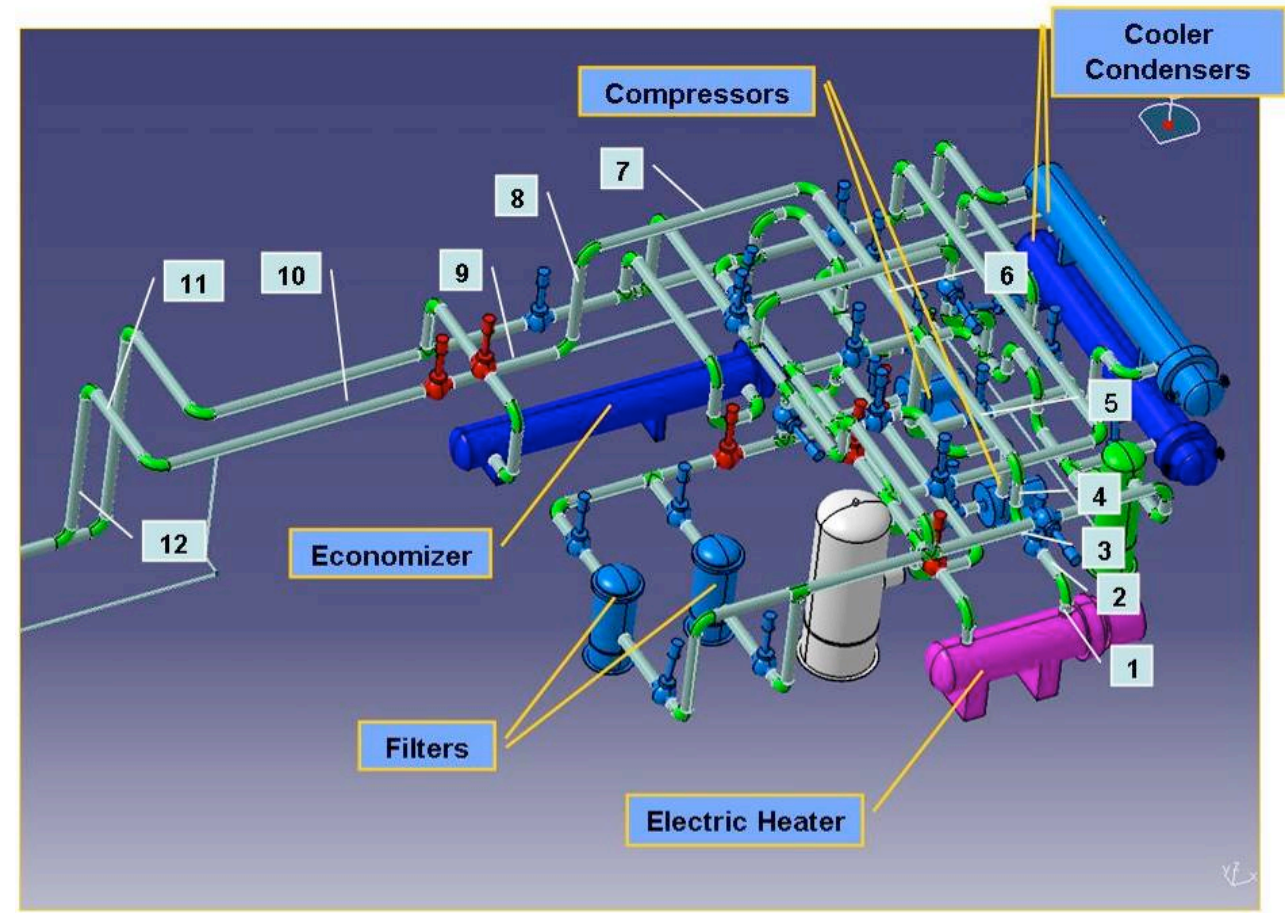

Fig. 1. Baking Gas Supply System-Heat Exchanger and Initial Piping.

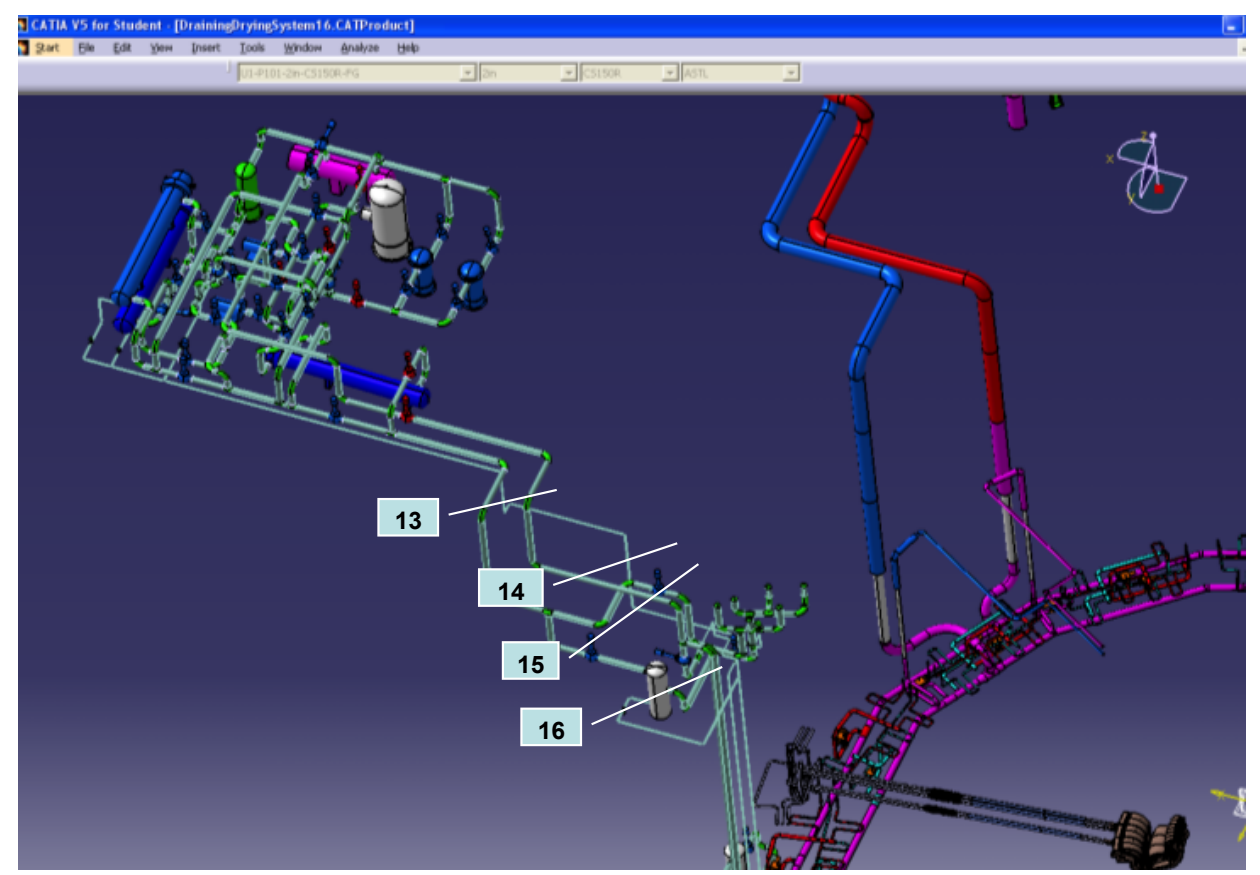

Fig. 2. Layout of Baking System Piping.

Figure 3 shows the gas baking piping (in blue) as it parallels the divertor system distribution headers. From this point, the baking gas flows into and through the distribution header, and through the normal branch piping to the divertor assembly. The 54 divertor cassettes are baked from 18 branch circuits, such 
that three divertor cassettes are baked in parallel, by one set of branch piping. The heat loss analysis in this report was performed for the branch piping that was at the end of the distribution header in order to pick the most conservative location for heat losses. Details of the distribution header-piping configuration are shown in Fig. 4. Branch piping that is not in use for baking is isolated from the remainder of the cooling water distribution headers during this process using the orange valves shown in Fig. 5. Also shown in Fig. 5 are the portions of the branch piping that attach to the distribution headers. Figure 6 shows the remainder of the branch piping leading to the divertor cassettes.

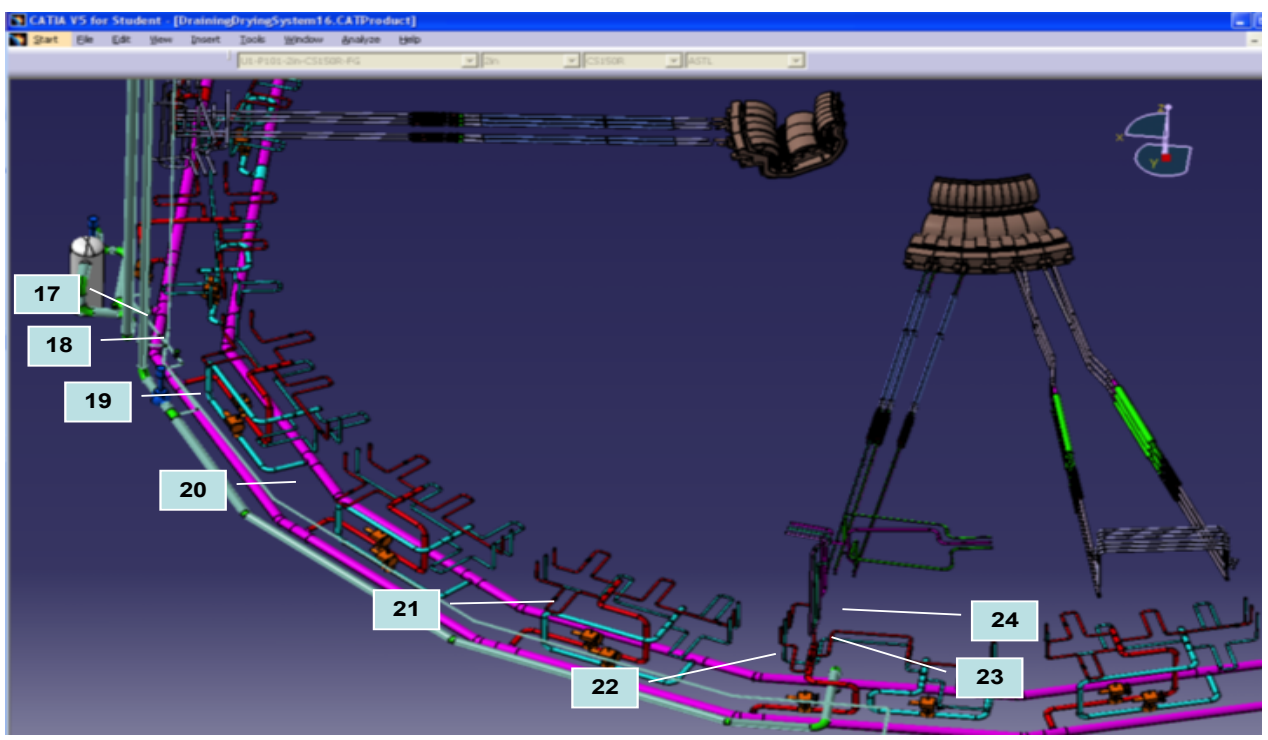

Fig. 3. Baking System Piping Connections to Divertor Distribution Header.

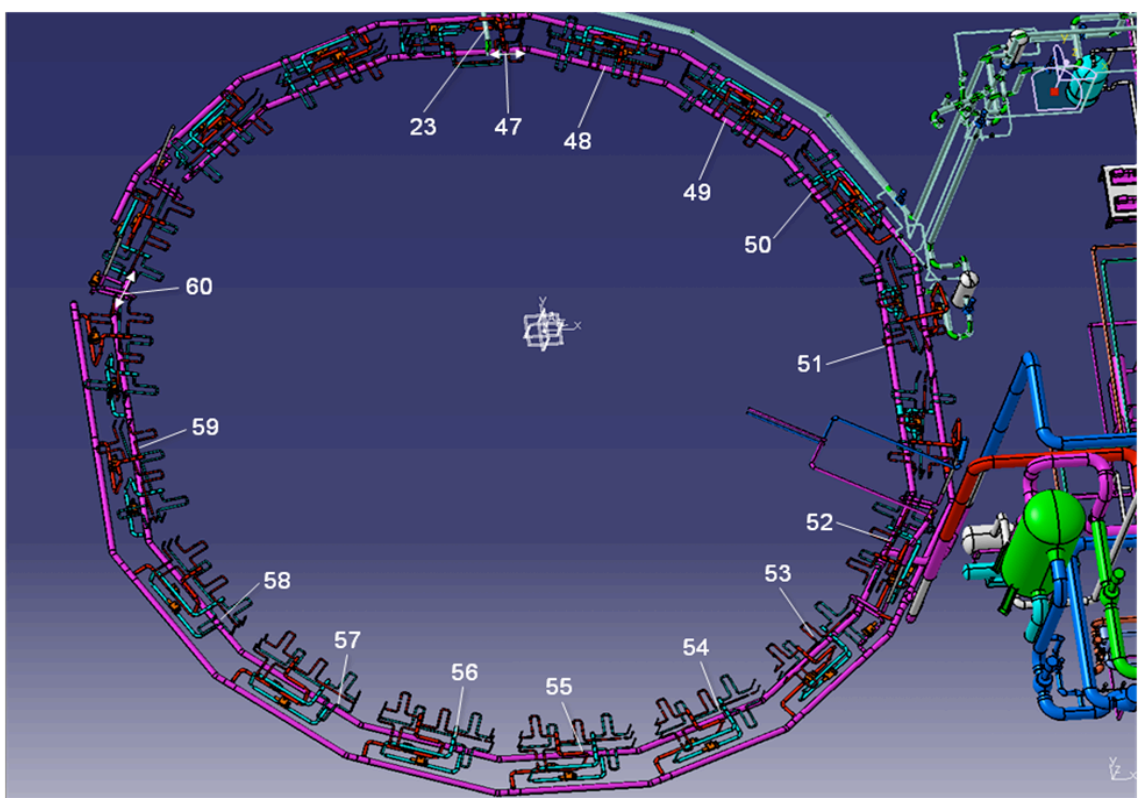

Fig. 4. Distribution Header Piping. 


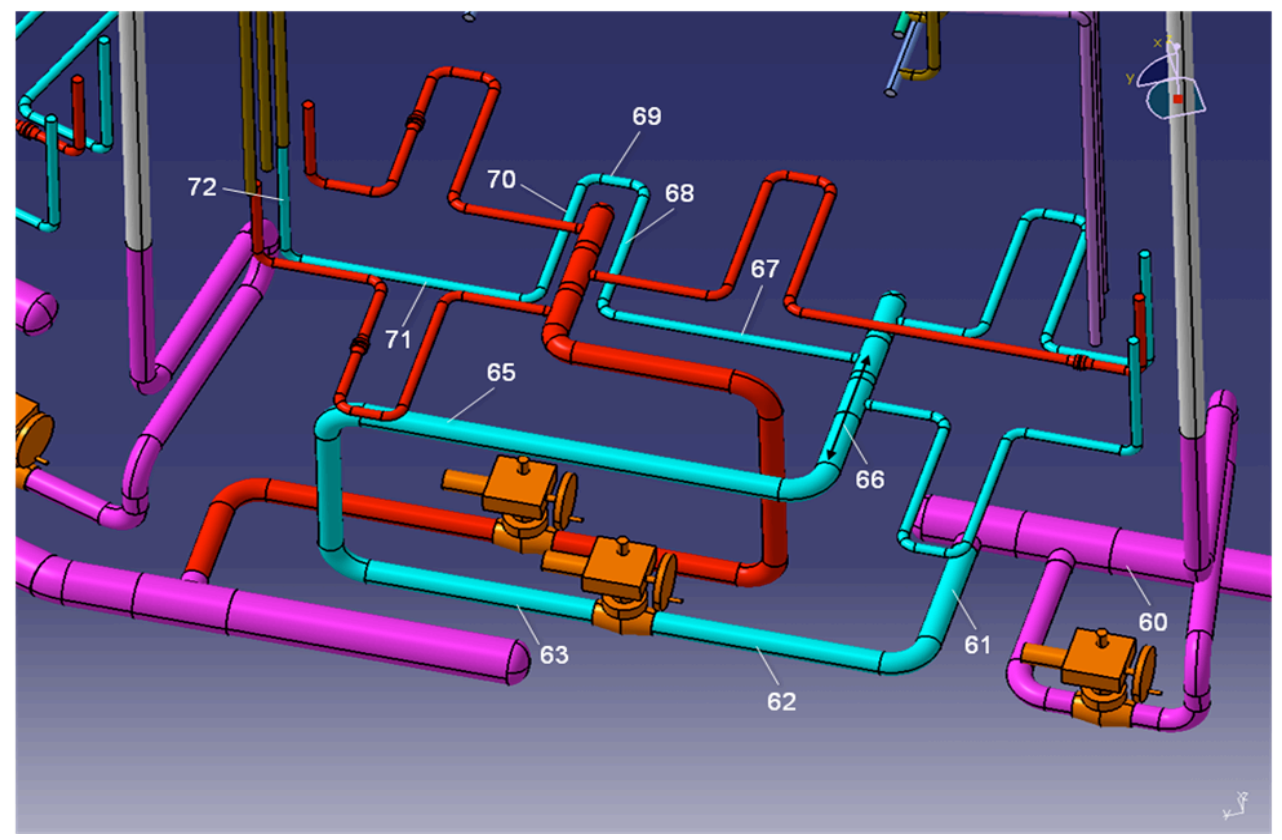

Fig. 5. Connection of Most Distant Branch Piping to Distribution Header (the brown colored piping in Fig. 5 and Fig. 6 [like pipe 75] were not included in the original CATIA model but were added for this analysis).

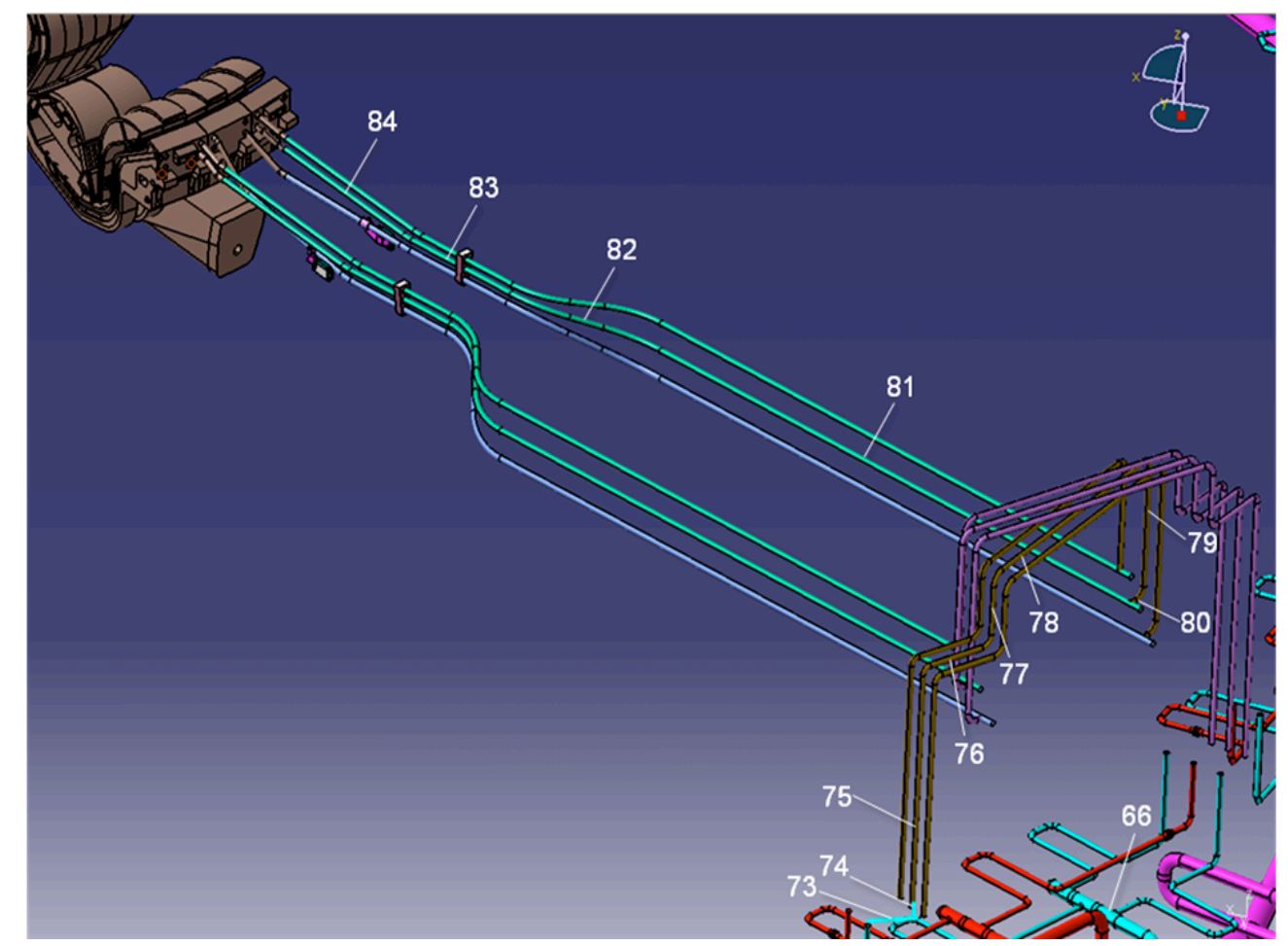

Fig. 6. Remainder to Divertor Branch Piping. 
A table of geometry was developed for each pipe segment in the previous schematics. Piping dimensions were taken from the CATIA representation of the gas baking system. Table 1 shows the geometry used in the analysis. Also shown in this table is the insulation thickness assumed in the analysis. This thickness was taken from a table developed for the ITER PHTS using the NAIMA 3E Plus computer program. The table provided the required insulation thickness necessary to keep the insulation outside surface temperature at $60^{\circ} \mathrm{C}$ (or lower) if the pipe were operating at $350^{\circ} \mathrm{C}$. All the CATIA models were taken from the configuration management models of the 2004 design. $^{2}$

Table 1. Piping geometry for gas baking

\begin{tabular}{|c|c|c|c|c|}
\hline Pipe number & Length (mm) & Diameter $(\mathbf{m m})$ & Schedule & $\begin{array}{l}\text { Insulation thickness } \\
\text { (mm) }\end{array}$ \\
\hline 1 & 224 & 250 & $80 \mathrm{~S}$ & 82.5 \\
\hline 2 & 1785 & 250 & $80 \mathrm{~S}$ & 82.5 \\
\hline 3 & 260 & 250 & $80 \mathrm{~S}$ & 82.5 \\
\hline 4 & 631 & 250 & $80 \mathrm{~S}$ & 82.5 \\
\hline 5 & 4055 & 250 & $80 \mathrm{~S}$ & 82.5 \\
\hline 6 & 4641 & 250 & $80 \mathrm{~S}$ & 82.5 \\
\hline 7 & 4884 & 250 & $80 \mathrm{~S}$ & 82.5 \\
\hline 8 & 2134 & 250 & $80 \mathrm{~S}$ & 82.5 \\
\hline 9 & 2587 & 250 & $80 \mathrm{~S}$ & 82.5 \\
\hline 10 & 6330 & 250 & $80 \mathrm{~S}$ & 82.5 \\
\hline 11 & 2238 & 250 & $80 \mathrm{~S}$ & 82.5 \\
\hline 12 & 3838 & 250 & $80 \mathrm{~S}$ & 82.5 \\
\hline 13 & 6438 & 250 & $80 \mathrm{~S}$ & 82.5 \\
\hline 14 & 2203 & 250 & $80 \mathrm{~S}$ & 82.5 \\
\hline 15 & 803 & 250 & $80 \mathrm{~S}$ & 82.5 \\
\hline 16 & 21838 & 250 & $80 \mathrm{~S}$ & 82.5 \\
\hline 17 & 573 & 250 & $80 \mathrm{~S}$ & 82.5 \\
\hline 18 & 332 & 250 & $80 \mathrm{~S}$ & 82.5 \\
\hline 19 & 4946 & 250 & $80 \mathrm{~S}$ & 82.5 \\
\hline 20 & 8276 & 250 & $80 \mathrm{~S}$ & 82.5 \\
\hline 21 & 8503 & 250 & $80 \mathrm{~S}$ & 82.5 \\
\hline 22 & 2250 & 250 & $80 \mathrm{~S}$ & 82.5 \\
\hline 23 & 2338 & 250 & $80 \mathrm{~S}$ & 82.5 \\
\hline 24 & 255 & 250 & $80 \mathrm{~S}$ & 82.5 \\
\hline 47 & 2005 & 300 & $80 \mathrm{~S}$ & 82.5 \\
\hline 48 & 7208 & 300 & $80 \mathrm{~S}$ & 77.5 \\
\hline 49 & 7208 & 300 & $80 \mathrm{~S}$ & 77.5 \\
\hline 50 & 7686 & 300 & $80 \mathrm{~S}$ & 77.5 \\
\hline 51 & 13399 & 300 & $80 \mathrm{~S}$ & 77.5 \\
\hline 52 & 7682 & 300 & $80 \mathrm{~S}$ & 77.5 \\
\hline 53 & 7217 & 300 & $80 \mathrm{~S}$ & 77.5 \\
\hline 54 & 7218 & 300 & $80 \mathrm{~S}$ & 77.5 \\
\hline 55 & 7208 & 300 & $80 \mathrm{~S}$ & 77.5 \\
\hline 56 & 7225 & 300 & $80 \mathrm{~S}$ & 77.5 \\
\hline 57 & 7208 & 300 & $80 \mathrm{~S}$ & 77.5 \\
\hline 58 & 7683 & 300 & $80 \mathrm{~S}$ & 77.5 \\
\hline 59 & 13399 & 300 & $80 \mathrm{~S}$ & 77.5 \\
\hline
\end{tabular}


Table 1 (continued)

\begin{tabular}{ccccc}
\hline Pipe number & Length $(\mathbf{m m})$ & Diameter $(\mathbf{m m})$ & Schedule & $\begin{array}{c}\text { Insulation thickness } \\
(\mathbf{m m})\end{array}$ \\
\hline 60 & 2387 & 300 & $80 \mathrm{~S}$ & 82.5 \\
61 & 987 & 150 & $80 \mathrm{~S}$ & 82.5 \\
62 & 1564 & 150 & $80 \mathrm{~S}$ & 77.5 \\
63 & 1564 & 150 & $80 \mathrm{~S}$ & 77.5 \\
64 & 1203 & 150 & $80 \mathrm{~S}$ & 77.5 \\
65 & 2875 & 150 & $80 \mathrm{~S}$ & 77.5 \\
66 & 1028 & 150 & $80 \mathrm{~S}$ & 77.5 \\
67 & 1662 & 65 & $80 \mathrm{~S}$ & 77.5 \\
68 & 1009 & 65 & $80 \mathrm{~S}$ & 60 \\
69 & 209 & 65 & $80 \mathrm{~S}$ & 60 \\
70 & 1009 & 65 & $80 \mathrm{~S}$ & 60 \\
71 & 1509 & 65 & $80 \mathrm{~S}$ & 60 \\
72 & 1123 & 65 & $80 \mathrm{~S}$ & 60 \\
73 & 658 & 65 & $80 \mathrm{~S}$ & 60 \\
74 & 500 & 65 & $80 \mathrm{~S}$ & 60 \\
75 & 3199 & 65 & $80 \mathrm{~S}$ & 60 \\
76 & 805 & 65 & $80 \mathrm{~S}$ & 60 \\
77 & 656 & 65 & $80 \mathrm{~S}$ & 60 \\
78 & 3292 & 65 & $80 \mathrm{~S}$ & 60 \\
79 & 1619 & 65 & $80 \mathrm{~S}$ & 60 \\
80 & 100 & 65 & $80 \mathrm{~S}$ & 60 \\
81 & 8176 & 65 & $80 \mathrm{~S}$ & 60 \\
82 & 446 & 65 & $80 \mathrm{~S}$ & 60 \\
83 & 1732 & 65 & $80 \mathrm{~S}$ & 60 \\
84 & 2119 & 65 & $80 \mathrm{~S}$ & \\
\hline
\end{tabular}

A CATIA representation of a single divertor cassette is shown in Fig. 7. The nitrogen flow from the branch piping splits to supply each of the three divertors on that branch circuit. Three parallel flow paths are also used to supply the surface of each divertor. Flow is split between each of the three divertor surfaces. Surface 1 is points 2 through 6 in Fig. 8, surface 2 is points 6 to 7, 8 to 9, and10 to 11 , and surface 3 is points 11 through 14. The body of the divertor itself acts as the manifold to supply each surface. Baking gas is supplied at the outer region of the divertor and is assumed to flow from point 2 to point 6 (Fig. 8), to the inner region of the diverter with flow from point 11 to point 14, and to the dome region from surfaces 6 to 7 , then 8 to 9 , and then 10 to 11 . The flow streams both within a single divertor and between the three divertors are then assumed to recombine and exit to the outlet branch piping. 


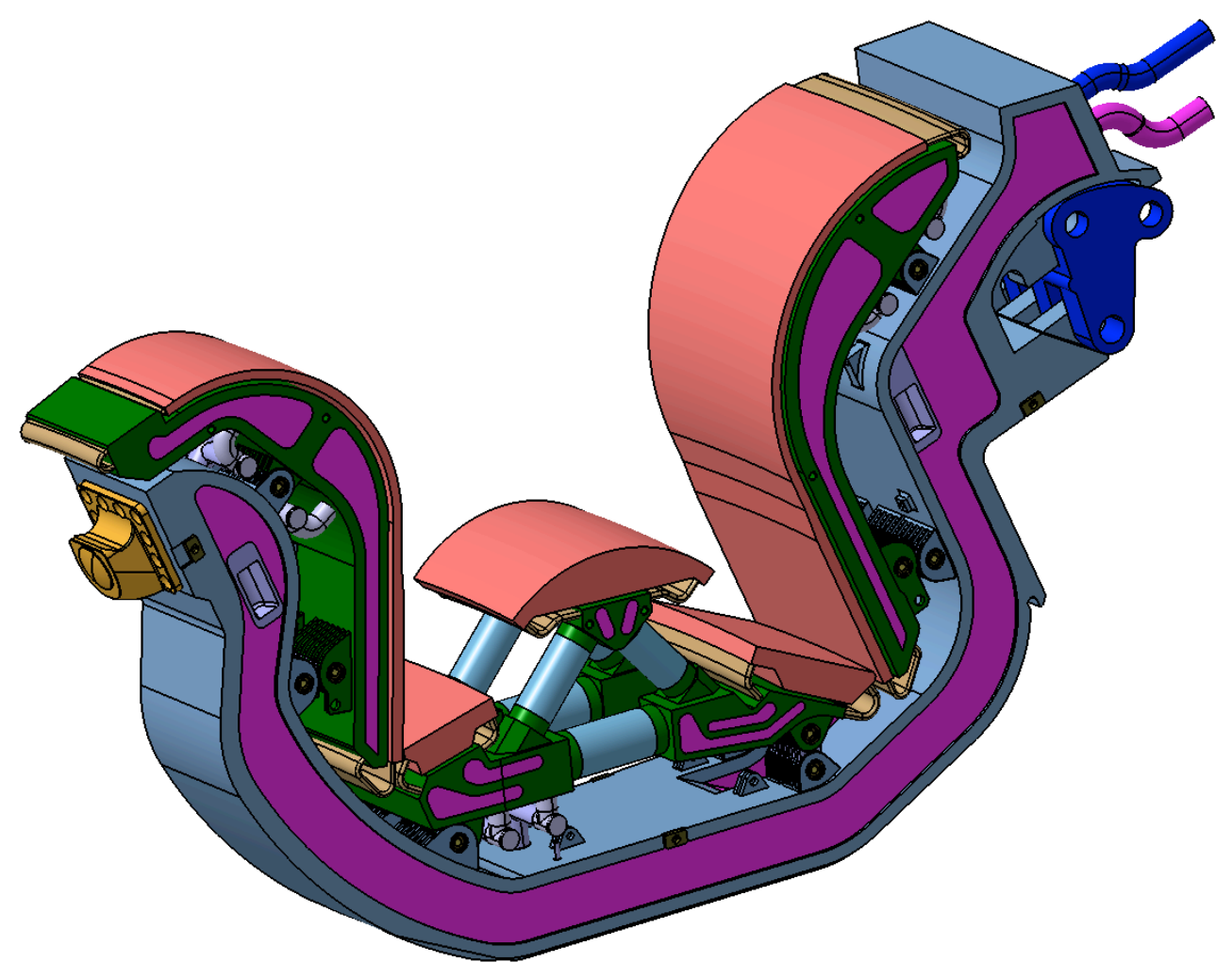

Fig. 7. Divertor from CATIA.

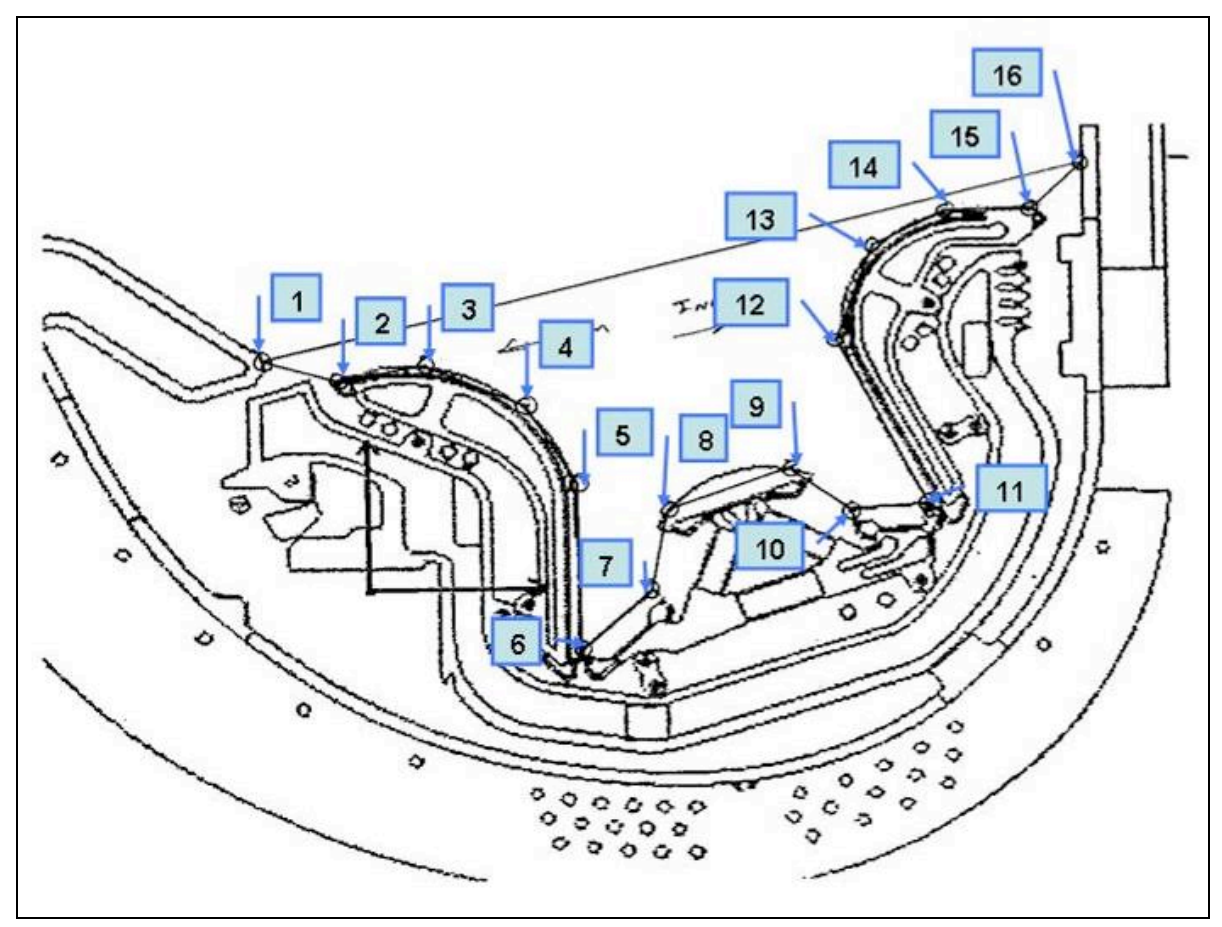

Fig. 8. Cross Section of a Divertor Cassette. 


\begin{abstract}
ANALYSIS
In order to calculate losses in the piping, a lumped parameter energy balance was applied to the gas flow in each piping section. For the analysis presented here, the baking gas was assumed to be nitrogen with a flow rate of $4.9 \mathrm{~kg} / \mathrm{s}$ and a pressure of $1 \mathrm{MPa}^{3}$ Losses were determined using one-dimensional radial heat transfer through the pipe and insulation. Constant properties were assumed for all calculations. Property values used in the calculations are presented in Table 2.
\end{abstract}

Table 2. Properties used in the heat loss calculations

\begin{tabular}{lll}
\hline \multicolumn{1}{c}{ Component } & \multicolumn{1}{c}{ Property } & \multicolumn{1}{c}{ Value } \\
\hline Stainless steel & Thermal conductivity & $19.5 \mathrm{w} / \mathrm{m} / \mathrm{K}$ \\
Insulation (fiberglass $\left.@ 260^{\circ} \mathrm{C}\right)$ & Thermal conductivity & $0.082 \mathrm{w} / \mathrm{m} / \mathrm{K}$ \\
Nitrogen $\left(350^{\circ} \mathrm{C}, 1 \mathrm{MPa}\right)$ & Thermal conductivity & $0.04539 \mathrm{w} / \mathrm{m} / \mathrm{K}$ \\
& Density & $5.3839 \mathrm{~kg} / \mathrm{m}^{3}$ \\
& Viscosity & $3.0446 \mathrm{e}-5 \mathrm{Ns} / \mathrm{m}^{2}$ \\
& Specific heat & $1.0828 \mathrm{~J} / \mathrm{g} / \mathrm{K}$ \\
& Pr (Prandt number) & 0.7263 \\
Air $\left(21^{\circ} \mathrm{C}, 0.1 \mathrm{MPa}\right)$ & Thermal conductivity & $0.025961 \mathrm{w} / \mathrm{m} / \mathrm{K}$ \\
& Density & $1.2222 \mathrm{~kg} / \mathrm{m}^{3}$ \\
& Viscosity & $1.78 \mathrm{e}-5 \mathrm{Ns} / \mathrm{m}^{2}$ \\
& Specific heat & $1.00483 \mathrm{~J} / \mathrm{g} / \mathrm{K}$ \\
& Pr & 0.687 \\
& Expansion coefficient & $3.38 \mathrm{e}-3 / \mathrm{K}$ \\
\hline
\end{tabular}

The heat transfer coefficient from the gas to the pipe wall was calculated using the Dittus-Boelter correlation. $^{4}$

$\mathrm{Nu}_{\mathrm{d}}=0.023 \operatorname{Re}_{\mathrm{d}}{ }^{0.4} \operatorname{Pr}^{0.3}$

where

$\mathrm{Nu}_{\mathrm{d}}-$ Nusselt number $\left(\mathrm{h}_{\mathrm{n}} \mathrm{d}_{\mathrm{p} i} / \mathrm{k}_{\mathrm{n}}\right)$,

$\operatorname{Re}_{\mathrm{d}}-$ Reynolds number $\left(\rho_{\mathrm{n}} \mathrm{d}_{\mathrm{pi}} / \mathrm{m}\right)$,

$\mathrm{h}_{\mathrm{n}}$ - heat transfer coefficient $\left(\mathrm{W} / \mathrm{m}^{2} / \mathrm{K}\right)$,

$\mathrm{d}_{\mathrm{pi}}-$ pipe inner diameter $(\mathrm{m})$,

$\mathrm{k}_{\mathrm{n}}-$ nitrogen thermal conductivity $(\mathrm{W} / \mathrm{m} / \mathrm{K})$,

$\mathrm{Pr}-$ nitrogen Prandtl number $\left(\mu_{\mathrm{n}} \mathrm{C}_{\mathrm{p}} / \mathrm{k}_{\mathrm{n}}\right)$,

$\mu_{\mathrm{n}}-$ nitrogen dynamic viscosity $\left(\mathrm{Ns} / \mathrm{m}^{2}\right)$,

$\mathrm{C}_{\mathrm{p}}-$ specific heat $(\mathrm{J} / \mathrm{g} / \mathrm{K})$, and

$\rho_{\mathrm{a}}-$ nitrogen density $\left(\mathrm{kg} / \mathrm{m}^{3}\right)$.

The natural circulation heat transfer coefficient on the outside surface of the insulation is calculated using one of two correlations, depending on the pipe orientation.

For a horizontal pipe orientation, a correlation presented in Bird, Stewart, and Lightfoot ${ }^{5}$ is used. 
$\mathrm{Nu}_{\mathrm{h}}=0.525(\mathrm{GrPr})^{1 / 4}$,

where

$\mathrm{Nu}_{\mathrm{h}}-$ Nusselt number $\left(\mathrm{h}_{\mathrm{h}} \mathrm{d}_{\mathrm{io}_{0}} / \mathrm{k}_{\mathrm{a}}\right)$,

$\mathrm{h}_{\mathrm{h}}$ - heat transfer coefficient in horizontal direction $\left(\mathrm{W} / \mathrm{m}^{2} / \mathrm{K}\right)$,

$\mathrm{Gr}-$ Grashof number $\left(\mathrm{d}_{\mathrm{io}}{ }^{3} \rho \mathrm{a}^{2} \mathrm{~g} \beta \Delta \mathrm{T} / \mu^{2}\right)$,

$\mathrm{d}_{\mathrm{io}}-$ insulation outer diameter $(\mathrm{m})$,

$\mathrm{k}_{\mathrm{a}}$ - air thermal conductivity $(\mathrm{W} / \mathrm{m} / \mathrm{K})$,

$\rho_{\mathrm{a}}-$ air density $\left(\mathrm{kg} / \mathrm{m}^{3}\right)$,

$\mathrm{g}$ - acceleration of gravity $\left(\mathrm{m} / \mathrm{s}^{2}\right)$,

$\beta$ - air expansion coefficient $(1 / \mathrm{K})$,

$\Delta \mathrm{T}$ - air-to-insulation temperature difference $(\mathrm{K})$, and

$\mu_{\mathrm{a}}-$ air dynamic viscosity $\left(\mathrm{Ns} / \mathrm{m}^{2}\right)$.

For a vertical pipe orientation, a correlation by Popiel ${ }^{6}$ is used.

$\mathrm{Nu}_{\mathrm{H}}=\mathrm{A} \mathrm{Ra}_{\mathrm{H}}{ }^{\mathrm{n}}$,

where

$\mathrm{A}=0.519+0.03454\left(\mathrm{H} / \mathrm{d}_{\mathrm{io}}\right)+0.0008772\left(\mathrm{H} / \mathrm{d}_{\mathrm{io}}\right)^{2}+8.855 \mathrm{e}-6\left(\mathrm{H} / \mathrm{d}_{\mathrm{io}}\right)^{3}$,

$\mathrm{n}=0.25-0.00253\left(\mathrm{H} / \mathrm{d}_{\mathrm{io}}\right)+1.152 \mathrm{e}-5\left(\mathrm{H} / \mathrm{d}_{\mathrm{io}}\right)^{2}$,

$\mathrm{Nu}_{\mathrm{v}}-$ Nusselt number $\left(\mathrm{h}_{\mathrm{v}} \mathrm{H} / \mathrm{k}_{\mathrm{a}}\right)$,

$\mathrm{h}_{\mathrm{v}}$ - heat transfer coefficient in vertical direction $\left(\mathrm{W} / \mathrm{m}^{2} / \mathrm{K}\right)$,

$\mathrm{H}$ - height of pipe (m),

$\mathrm{k}_{\mathrm{a}}$ - thermal conductivity $(\mathrm{W} /(\mathrm{Km})$

$\mathrm{Ra}$ - Rayleigh number $\left(\mathrm{Gr}_{\mathrm{H}} \mathrm{Pr}\right)$, and

$\mathrm{Gr}_{\mathrm{H}}-$ Grashof number $\left(\mathrm{H}^{3} \rho_{\mathrm{a}}{ }^{2} \mathrm{~g} \beta \Delta \mathrm{T} / \mu_{\mathrm{a}}{ }^{2}\right)$.

Radiation from the outer insulation surface to the ambient is also assumed to occur. The radiation heat transfer, $\mathrm{Q}_{\mathrm{rad}}$, is added to that from natural convection:

$\mathrm{Q}_{\mathrm{rad}}=\mathrm{A}_{\mathrm{i}} \varepsilon_{\mathrm{i}} \sigma\left(\mathrm{T}_{\mathrm{io}}{ }^{4}-\mathrm{T}_{\mathrm{a}}{ }^{4}\right)$,

where

$\varepsilon_{\mathrm{i}}$ - emissivity of the outer insulation surface,

$\mathrm{A}_{\mathrm{i}}$ - insulation outer surface area $\left(\mathrm{m}^{2}\right)$,

$\sigma$ - Stefan-Boltzmann constant $\left(\mathrm{W} / \mathrm{m}^{2} / \mathrm{k}^{4}\right)$,

$\mathrm{T}_{\mathrm{io}}$ - insulation outer surface temperature, $\left({ }^{\circ} \mathrm{C}\right)$, and

$\mathrm{T}_{\mathrm{a}}-$ ambient air temperature $\left({ }^{\circ} \mathrm{C}\right)$.

The piping heat loss calculation incorporates conduction through the stainless steel piping and insulation and uses the following equation: 
$\mathrm{Q}=\mathrm{UA} \mathrm{A}_{\mathrm{pi}}\left(\mathrm{T}_{\mathrm{io}}-\mathrm{T}_{\mathrm{a}}\right)$

where

$\mathrm{U}=1 /\left(1 / \mathrm{h}_{\mathrm{n}}+\mathrm{d}_{\mathrm{pi}} / 2 / \mathrm{k}_{\mathrm{ss}} \ln \left(\mathrm{d}_{\mathrm{po}} / \mathrm{d}_{\mathrm{pi}}\right)+\mathrm{d}_{\mathrm{pi}} / 2 \mathrm{k}_{\mathrm{i}} \ln \left(\mathrm{d}_{\mathrm{io}} / \mathrm{d}_{\mathrm{ii}}\right)+\mathrm{d}_{\mathrm{pi}} / \mathrm{d}_{\mathrm{io}} / \mathrm{h}^{*}\right)$,

$\mathrm{Q}$ - energy loss through pipe and pipe insulation (W),

$\mathrm{A}_{\mathrm{pi}}$ - pipe inside area $\left(\mathrm{m}^{2}\right)$,

$h^{*}-$ either $h_{v}$ or $h_{h}$ depending on the pipe orientation, and

$\mathrm{k}_{\mathrm{ss}}-$ stainless steel thermal conductivity $\left(\mathrm{W} / \mathrm{m}^{2} / \mathrm{K}\right)$.

The outlet temperature of one piping segment is used as the inlet temperature for the next piping segment as the nitrogen progresses toward the divertor.

Losses through piping supports were also considered. A simplified piping support was modeled. A support was envisioned that is welded directly to the piping in a cross geometry with one leg of the cross oriented axially along the pipe and the other leg oriented circumferentially around the pipe. Each leg of the cross was assumed to be made up of $25.4 \mathrm{~mm}$ thick stainless steel. The length of each leg was assumed to be one-third the circumference of the pipe. The cross was assumed to extend $25.4 \mathrm{~mm}$ beyond the insulation thickness at which point the temperature of the support was assumed to be $21^{\circ} \mathrm{C}$. Because the support was assumed to be surrounded by insulation, the only heat losses were assumed to occur from the pipe surface to the point assumed to be $21^{\circ} \mathrm{C}$. Piping supports were arbitrarily assumed to be placed every $6.1 \mathrm{~m}$ along the piping length. Support losses per meter of pipe were then calculated and added to the other piping losses. A schematic of the support is shown in Fig. 9.

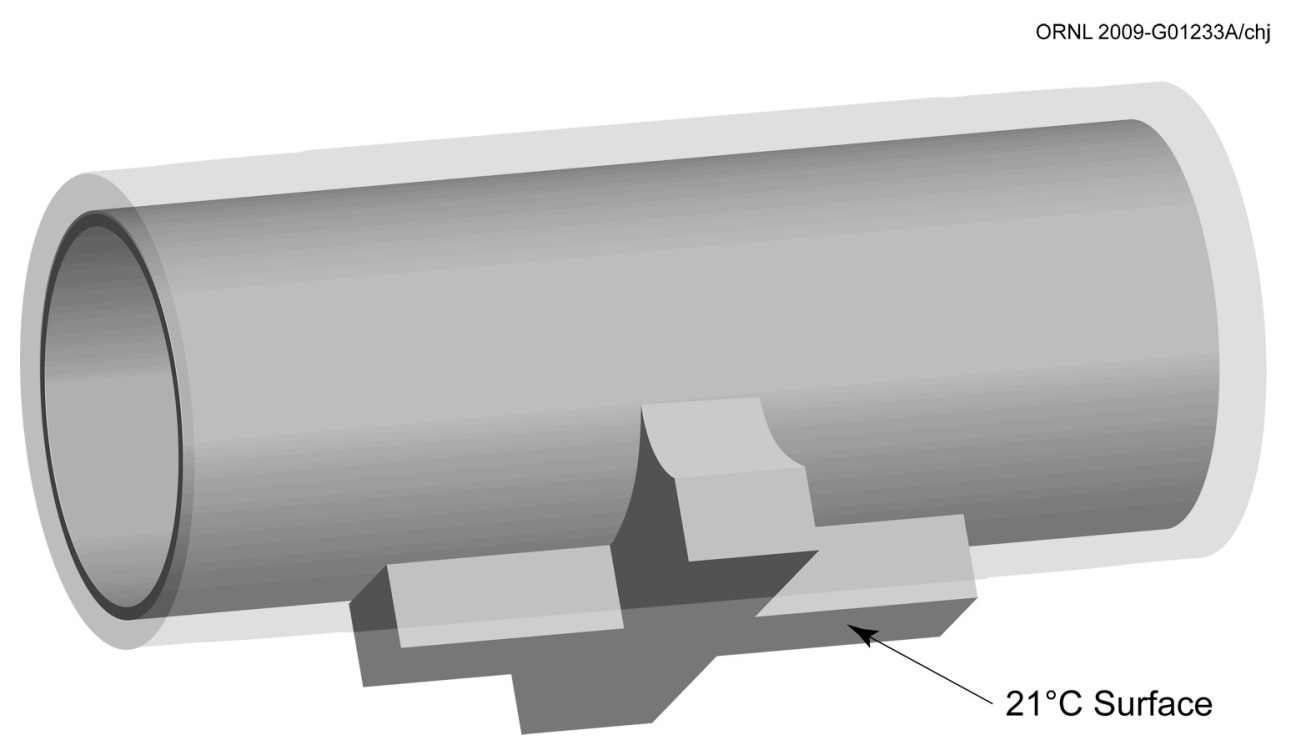

Fig. 9. Representation of a Generic Pipe Support.

During the baking process, the plasma chamber is assumed to be under vacuum, and the heat loss from the divertor is assumed to all be from radiation. In order to perform the radiation calculations, radiation from the divertor was assumed to be two-dimensional. View factors from the divertor top surface to the vacuum vessel (and between components) were calculated by dividing the divertor surfaces into flat segments as indicated in Fig. 8. The points at the ends of each of the segments were digitized. View 
factors for each segment were then calculated using Hottel's crossed string method $^{7}$ (see Fig. 10 for reference).

$\mathrm{F}_{\mathrm{ik}}=\left(\mathrm{L}_{\mathrm{ik}}+\mathrm{L}_{\mathrm{jl}}-\mathrm{L}_{\mathrm{i} 1}-\mathrm{L}_{\mathrm{jk}}\right) /\left(2 \mathrm{~A}_{\mathrm{i}}\right)$,

where

$F_{i k}$ - view factor between surface $A_{i}$ and $A_{k}$,

$A_{i}$ - area of surface $i\left(\mathrm{~m}^{2}\right)$, and

$\mathrm{L}_{\mathrm{ij}}$ - length of line from point $\mathrm{i}$ to point $\mathrm{j}(\mathrm{m})$.

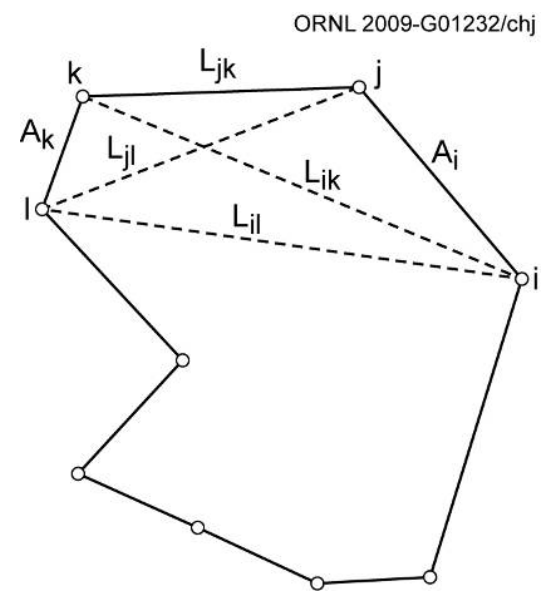

Fig. 10. Cross Strings Method.

Divertor surface area values were taken from CATIA drawings. The line lengths for each divertor segment (from the digitization process discussed above) were summed, and a value for line length per surface area was calculated. This value was then used to determine the effective surface area for each segment used in the radiation calculations. The divertor surface areas facing the vacuum vessel (upward) that were assumed in the analysis are shown in Table 3. The calculations assumed that three divertors were serviced at one time by the baking system, and that the blanket surfaces surrounding the divertor in the plasma chamber were at $240^{\circ} \mathrm{C}$, and that the vacuum vessel was at $200^{\circ} \mathrm{C}$; that is, that the vacuum vessel and other components within the plasma chamber were also at their baking temperatures. The blanket emissivity was assumed to be 1 , the divertor surface emissivity was assumed to be $0.7,{ }^{3}$ and the emissivity of steel was assumed to be 0.3 .

Table 3. Assumed divertor surface areas

\begin{tabular}{lc}
\hline \multicolumn{1}{c}{ Divertor section } & Area $\left(\mathbf{m}^{\mathbf{2}}\right)$ \\
\hline Inner divertor & 3.04 \\
Divertor dome & 5.06 \\
Outer divertor & 4.33 \\
\hline
\end{tabular}




\section{RESULTS}

Calculations were performed using the above assumptions to determine the nitrogen inlet temperature necessary to meet the $350^{\circ} \mathrm{C}$ divertor baking requirement. Table 4 shows the nitrogen exit temperature for each of the piping segments of Table 1. In addition, the outlet temperature for each part of the divertor is shown. As implied by the calculations, in order to get a gas temperature in the divertor of $350^{\circ} \mathrm{C}$, a nitrogen inlet temperature to the gas baking piping of $380^{\circ} \mathrm{C}$ is required.

Table 4. Pipe segment outlet temperature

\begin{tabular}{|c|c|}
\hline Pipe number & $\begin{array}{c}\text { Outlet temperature } \\
\left({ }^{\circ} \mathbf{C}\right)\end{array}$ \\
\hline Inlet temperature & 380.0 \\
\hline 1 & 379.9785 \\
\hline 2 & 379.8079 \\
\hline 3 & 379.783 \\
\hline 4 & 379.7228 \\
\hline 5 & 379.3354 \\
\hline 6 & 378.8925 \\
\hline 7 & 378.427 \\
\hline 8 & 378.2252 \\
\hline 9 & 377.9791 \\
\hline 10 & 377.3773 \\
\hline 11 & 377.1649 \\
\hline 12 & 376.8041 \\
\hline 13 & 376.1941 \\
\hline 14 & 375.9871 \\
\hline 15 & 375.9112 \\
\hline 16 & 373.8895 \\
\hline 17 & 373.8356 \\
\hline 18 & 373.8045 \\
\hline 19 & 373.3398 \\
\hline 20 & 372.5633 \\
\hline 21 & 371.7673 \\
\hline 22 & 371.5572 \\
\hline 23 & 371.3389 \\
\hline 24 & 371.3151 \\
\hline 47 & 371.0985 \\
\hline 48 & 370.3018 \\
\hline 49 & 369.5068 \\
\hline 50 & 368.6624 \\
\hline 51 & 367.2078 \\
\hline 52 & 366.3508 \\
\hline 53 & 365.564 \\
\hline 54 & 364.7789 \\
\hline 55 & 363.9967 \\
\hline 56 & 363.2144 \\
\hline 57 & 362.4358 \\
\hline 58 & 361.609 \\
\hline 59 & 360.1659 \\
\hline
\end{tabular}


Table 4 (continued)

\begin{tabular}{|c|c|}
\hline Pipe number & $\begin{array}{c}\text { Outlet temperature } \\
\left({ }^{\circ} \mathrm{C}\right)\end{array}$ \\
\hline 60 & 359.9163 \\
\hline 61 & 359.8541 \\
\hline 62 & 359.7554 \\
\hline 63 & 359.6568 \\
\hline 64 & 359.5814 \\
\hline 65 & 359.4003 \\
\hline 66 & 359.3355 \\
\hline 67 & 359.2709 \\
\hline 68 & 359.2317 \\
\hline 69 & 359.2236 \\
\hline 70 & 359.1844 \\
\hline 71 & 359.1257 \\
\hline 72 & 359.0825 \\
\hline 73 & 359.0569 \\
\hline 74 & 359.0376 \\
\hline 75 & 358.9152 \\
\hline 76 & 358.884 \\
\hline 77 & 358.8587 \\
\hline 78 & 358.7309 \\
\hline 79 & 358.6688 \\
\hline 80 & 358.6649 \\
\hline 81 & 358.3477 \\
\hline 82 & 358.3304 \\
\hline 83 & 358.2633 \\
\hline 84 & 358.1812 \\
\hline Divertor section 2-3 & 356.3171 \\
\hline Divertor section 3-4 & 354.3696 \\
\hline Divertor section 4-5 & 353.0389 \\
\hline Divertor section 5-6 & 350.8839 \\
\hline Divertor section 6-7 & 355.5322 \\
\hline Divertor section 8-9 & 353.437 \\
\hline Divertor section $10-11$ & 352.6808 \\
\hline Divertor section 11-12 & 354.1329 \\
\hline Divertor section $12-13$ & 351.6652 \\
\hline Divertor section 13-14 & 350.7944 \\
\hline
\end{tabular}

\section{CONCLUSIONS}

These simplified calculations have shown that in order to have a minimum gas temperature in the divertor of $350^{\circ} \mathrm{C}$, the gas baking system heater must supply $380^{\circ} \mathrm{C}$ nitrogen at the entrance of the gas baking system piping. These calculations have assumed that the system is at steady state. The radiation heat transfer in the vacuum vessel has been greatly simplified, and in order to develop a more accurate estimate, more detailed calculations in that region need to be performed. The back side of the plasma facing surfaces of the divertor that face downward were not considered in the present analysis, because it was thought that there were several surfaces between the divertor and the vacuum vessel would act as radiation shields (mounting structure, flow channels, etc.), and would significantly reduce the radiation 
losses in that direction. However this assumption needs to be checked. Conduction through the divertor support systems also needs to be considered but was not included in this analysis, no hand calculations have been made of the losses through the supports. Additionally, more detailed calculations of losses through piping supports need to be undertaken, using actual support geometry and spacings. These calculations were all steady state, and if it is of interest to determine how long it takes to get to the desired baking temperatures, it will be necessary to perform transient analysis accounting for the heat capacity of the structures. This could be accomplished using a RELAP calculation or other such system analysis code as well as an adiabatic calculation to see what the minimum temperature rise time would be versus flow rate and temperature.

\section{REFERENCES}

1. P. Andrew and W. Shu, "Rationale for $350^{\circ} \mathrm{C}$ Divertor Baking," presentation at ITER International Organization, Cadarache, France, April 25, 2008.

2. Configuration management model (CMM) of the lower pipe chase, 2004 design.

3. G. Dell'Orco, "Baking the Divertor at $350^{\circ} \mathrm{C}$ Main Characteristics and Performance," presentation at ITER International Office, Cadarache, France, June 18, 2008.

4. F. W. Dittus and L. M. K. Boelter, University of California Publications in Engineering, 2:443, 1930.

5. R. B. Bird, W. E. Stewart, and E. N. Lightfoot, 1963. Transport Phenomena, John Wiley \& Sons, Inc., Third Printing, 1968.

6. C. O. Popiel, "Free Convection Heat Transfer from Vertical Slender Cylinders: A Review," Heat Transfer Engineering 29(6), 521-536 (2008).

7. J. I. Eichberger, "Calculation of Geometric Configuration Factors in an Enclosure Whose Boundary Is Given by an Arbitrary Polygon in the Plane," Wärme-und Stoffübertragung 19, 269-271 (1985).

8. Personal communication with Marc Lamarre, ITER 3D CAD 2009 Dec 2009. 


\section{INTERNAL DISTRIBUTION}

1. Jan Berry

2. Jeremy Duncan

3. Juan Ferrada

4. Karen Harvey

5. Seokho Kim
6. Brad Nelson

7. Roy Shearin

8. Grady Yoder

9. File-USIPO DCC-RC

\section{EXTERNAL DISTRIBUTION}

10. Joe Stringer, AREVA NP, Inc.

11. Warren Curd, ITER Organization

12. Giovanni Dell'Orco, ITER Organization 